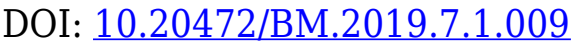

\title{
DETERMINANTS OF FINANCIAL INCLUSION IN EAST AFRICA
}

\author{
VICTORIA WANJIKU WOKABI, OLANREWAJU ISOLA FATOKI
}

\begin{abstract}
:
There is a growing focus on financial inclusion among scholars and in policy circles. This study sought to analyse the underlying determinants of financial inclusion among five East African countries- Kenya, Uganda, Tanzania, Rwanda and Burundi. The general objective of the study was to determine the determinants of financial inclusion in East Africa. Specifically, the study examined the effect of rural population, unemployment rates, income level and interest rates on financial inclusion. Rural population was presented as the proportion of a country's population that lives in rural areas; unemployment rate as the proportion of a country's population that is unemployed; income as the annual growth rate in GDP per capita; and interest rate as the real interest rate per year. The study used domestic credit to private sector by banks as a measure of financial inclusion The research design used was panel data analysis with secondary data collected from the World Development Indicators database of the World Bank. The 17 year period covered by the study spanned 2000 to 2016. The data was analysed on Stata and the output from analysis provided a basis for findings and recommendations. After conducting diagnostic tests, the model adopted for the study was the fixed effects model. The study found that rural population and income are significant determinants of financial inclusion with rural population being negatively related with financial inclusion. This means that the higher the rural population of a country, the less inclusive their financial system is. Unemployment though statistically insignificant had a negative relationship with financial inclusion. Interest rates had a positive but insignificant relationship with financial inclusion. The study recommended that focused financial literacy efforts be increased in the rural areas within East Africa to promote inclusion efforts. Interest rates can be a powerful policy tool to encourage both savings and credit facility sourcing from the banking sector.
\end{abstract}

\section{Keywords:}

Financial inclusion, financial exclusion, East Africa, panel data

\section{Authors:}

VICTORIA WANJIKU WOKABI, KCA University, Kenya, Email: victoriawawokabi@gmail.com OLANREWAJU ISOLA FATOKI, KCA University, Kenya, Email: lanrefatoki@gmail.com

\section{Citation:}

VICTORIA WANJIKU WOKABI, OLANREWAJU ISOLA FATOKI (2019). Determinants of Financial Inclusion In East Africa. International Journal of Business and Management, Vol. VII(1), pp. 125-143., 10.20472/BM.2019.7.1.009 


\subsection{Introduction}

The ability to concisely define financial inclusion is key to developing a framework and identifying the factors that drive it. However, there is no one agreed upon definition of financial inclusion as this varies depending on geographies, economic, social and financial progress of the regions in question and even the priorities of concern from both a social and economic stand-point. Financial inclusion in the most basic of definitions means unbiased access to financial services in an indiscriminate and straightforward way at affordable costs (Cnaan, Handy \& Moodithaya, 2012; Sarma, 2008). The term 'Financial Inclusion' was first coined in British vocabulary when it was found that over 7 million people did not have a bank account. Fuller and Mellor (2008) approached financial inclusion as a need to come up with welfare oriented reliable and affordable financial services for all in a population. There are authors who however believe that financial inclusion is a market-driven solution aimed at alleviation of poverty (Alpana, 2007). Regardless of motivation, all authors agree that financial inclusion is the desired outcome as the marginalised in society can access financial services at an affordable rate and minimise the ravages of poverty.

The World Bank defines financial inclusion as that share of individuals and firms that use financial services i.e. transactions, payments, savings, credit and insurance. This paper focuses on the savings and credit aspects. The World Bank and scholars (Johnston \& Murdoch, 2002) however point out that there is a distinction between financial inclusion and access to finance. There are individuals who prefer to not access credit, others not to save. Others are not creditworthy and as such cannot have credit facilities extended to them. Lack of use of financial services in itself does not necessarily equate to a lack of access.

Financial inclusion has been hailed as an enabler of seven of the seventeen sustainable development goals. Since 2010, over 55 countries had committed to having a national strategy geared towards financial inclusion. Countries have taken bold steps such as Mexico where a presidential decree was issued to form a council whose mandate is to organise different stakeholders working towards financial inclusion in the country. Colombia on the other hand brought together different ministries to form the Financial Inclusion Committee to supervise efforts by the organ created to promote access to financial services for the unbanked of Colombia. India took a different approach, opting to launch the National Mission on Financial Inclusion. Its mandate includes provision of access to transaction accounts by all households. Financial literacy backed with access to credit, micro-insurance and pension are also key deliverables of the Mission. Similar commissions are in place in Tanzania, Madagascar, Paraguay, Peru, Namibia and Nigeria (World Bank, 2017).

Closer home, in East Africa, strides are being made to ensure that access to financial services for all is promoted. Some countries like Burundi, based on a World Bank report dated 2017 had only 7\% of its population with a bank account. Uganda in 2017 launched its National Financial Inclusion Strategy 2017-2022. The strategy seeks to reduce financial exclusion to $5 \%$ by 2022. Rwanda on the other hand considers financial inclusion an integral enabler to achieving its development and poverty reduction objectives. Rwanda aims for a $90 \%$ financial inclusion by 2020. Tanzania also has in place a National Financial Inclusion Framework (NFIF 2018-2022) whose objective is to drive provision of financial goods and services that serve individuals and business needs in line with supporting livelihood and job creation.

The World Bank classifies types of indicators to take into consideration when measuring financial inclusion. These are access/ penetration measured by depositors with commercial banks (per 1000 adults); availability of services measured by bank branches per 100,000 people ; usage of services measured by volume of credit and deposits as a proportion of a 
country's GDP and quality of products. The most commonly used indicator is number of depositors with commercial banks (per 1000 adults) (Čihák, Demirgüç-Kunt, Feyen \& Levine, 2012; Naceur, Barajas \& Massara, 2015). However, concerns have been raised on the use of an individual indicator as this only provides partial information on the inclusive tendencies in an economy. A more appropriate measure should consider as many aspects of financial inclusion as possible; should compare easily across countries and should be easy to compute.

A study by Demirguc-Kunt and Klapper (2013) found that $23 \%$ of the adults in Africa hold formal bank accounts. This figure however varies depending on the region under study. Only $24 \%$ of adults in Sub-Saharan Africa have an account, though for Southern Africa this is at $51 \%$ compared against the $11 \%$ of Central Africa. North Africa had $20 \%$ of its adults banked with Eastern Africa at $28 \%$. This however varies within the countries themselves.

In Africa, the adult population with a bank account is highest in Mauritius at $80 \%$ and South Africa at $54 \%$. More than 10 countries have less than $10 \%$ of their adult population banked. These include Guinea, Niger, Congo and Central African Republic. These statistics compare against high income nations of the world where account ownership stands at $89 \%$ (DemirgucKunt and Klapper, 2013).

Mobile money innovations have promoted financial inclusion in Africa with Kenya being a pioneer. Even with such strides, exclusion is still happening on other fronts. Gender inequality is driving the rift, where $30 \%$ of women in Sub-Saharan Africa have an account compared to $39 \%$ of the men. Only $25 \%$ of adults in the poorest $40 \%$ of households have an account compared to the $46 \%$ of the richest $60 \%$ (Demirguc-Kunt \& Klapper, 2013).

Some of the reasons given for the poor comparison include the amount required to operate an account. In Sierra Leone and Uganda, a sum equivalent of $50 \%$ of per capita GDP is required to open a checking account. Uganda and Zimbabwe further have a unique challenge where maintenance fees for a checking account amount to a fifth of the per capita GDP. Some countries in the developed nations do not have a fee to the checking account (Beck \& Demirgüç-Kunt, 2006; Oyelami, Saibu \& Odenkule, 2017).

\subsection{Statement of the Problem}

Financial inclusion has been considered instrumental in alleviation of poverty and promotion of financial prosperity in many countries. In Mongolia, a study found a significant relationship between group loans and food consumption with food being more and healthier (Attanasio, Britta, Ralph, Emla \& Heike, 2011). A study by Bauchet, Cristobal, Laura, Jeanette and Yalouris (2011) suggested that financial services positively influence self-employment, business activities and even household consumption. In South Africa, access to consumer credit increased borrower's wellbeing, status in community and even income and food consumption (Karlan \& Zinman, 2010).

On a more macroeconomic level, greater financial inclusion translates to government's reduced costs when executing social policies. Over $25 \%$ of variation across countries in poverty reduction rates is attributable to cross country variation in financial development (Beck, Demirgüç-Kunt \& Levine 2007). The World Bank through a 2012 study suggested that increased financial inclusion also increases financial stability.

Even with focus on increasing access to financial services for all, there is still a need to understand the factors hindering nationals from having bank accounts, saving in them and even seeking credit. To improve access to financial services, it is imperative that 
governments, financial institutions and their partners also make an effort to understand and therefore remove any barriers that hamper development due to financial exclusion.In the last decade, research has been conducted to determine reasons for formal financial exclusion. Most studies centre on the idea of a 'household' and seek to identify the reasons why these remain unbanked. Beck and Brown (2011) found that the use of banking products is more common in households where there is higher income, formal employment, adults have higher education and are located in the urban areas.

There is a general consensus that financial inclusion is imperative for economic development However, few studies have been undertaken with a focus on determinants of financial inclusion for the countries in East Africa. The studies have been on a global scale with some African countries being quoted and cited. For this reason, the author pursued this research to study the variables that influence the level of financial inclusion in the East African countries and thus provide a framework against which policy can be formulated and implemented to increase financial inclusion.

\subsection{General Objective}

This study was focused on determinants and extent to which these determinants influence financial inclusion in 5 East African countries between 2000 and 2016 and was limited to Kenya, Uganda, Tanzania, Burundi and Rwanda. The general objective of this study was to empirically test the determinants of financial inclusion among East African Countries. The specific objectives of this study were:

i) To determine the effect of rural population size on financial inclusion among East African countries

ii) To determine how income level influences financial inclusion among East African countries

iii) To determine the influence of unemployment rates on financial inclusion among East African countries

iv) To examine how interest rates influence financial inclusion among East African countries

\section{$2.0 \quad$ Literature Review}

\subsection{Theoretical Review}

This study was guided by two theories; The Finance Growth Nexus Theory and The Theory of Information Asymmetry.

The Finance-Growth Nexus Theory is framed against assumptions of perfect information, frictionless economy and mobile resources and demonstrates the link between financial spheres and the real economy. First proposed by Walter Bagehot (1873), it points to how events in the money market affect capital spill overs in an economy as people seek the most profitable and worthy ways to use funds. Essentially, loanable funds spur economic activity. There is a multiplicative effect in the advancement of credit. This theory forms a pillar in identifying characteristics that influence financial inclusion among those in the informal sector and identifies the need for funds to be provided where they are most needed. It further points to the role that financial institutions play in bridging the financial inclusion gap through innovatively bringing the excluded into the fray. This is essentially the definition of financial 
inclusion. The theory therefore sets the tone for the case for financial inclusion and the need for policies to be in place to promote the same.

The Theory of Asymmetric Information. Proposed in the 1970s and 1980s by George Akerlof in the 1970 paper, "The Market for 'Lemons': Quality Uncertainty and the Market Mechanism", the Theory of Asymmetric Information observes that inefficient outcomes in the market can be as a result of imbalance between buyers and sellers. The theory explains how and why some financial inclusion efforts fail due to non-disclosure of pertinent information leading to mistrust between the public and financial institutions. A lack of transparency on the prevailing circumstances of a borrower including income level and employment status can deter financial inclusion efforts.

\section{$2.2 \quad$ Empirical Review}

Literature distinguishes between two types of financial exclusion: involuntary self-exclusion and voluntary self-exclusion (de Koker \& Jentzsch, 2011). Voluntarily self-excluded people opt not to use financial services as they may have no need for them or have cultural reasons not to. They lack faith in the formal sector or may not meet certain eligibility criteria. There is a third group; that of individuals who initially use financial services but then later withdraw. Reasons for this vary from lack of trust to bad credit records (Olaniyi, E. \& Babatunde, A., 2016).

A number of models have been suggested to classify the barriers to financial inclusion. Overall, an agreement on the existence of supply side and demand side barriers has been reached. On the supply side, literature explains how the structure, set up and accessibility of financial institutions leads to the unbanked status of some households. Households considered to be poor will mostly borrow for needs that offer no returns such as health care and weddings. This could make banks reluctant to offer the loans as there is no guarantee of pay-back (Claessens, 2006).

The definition of core versus non-core business is another barrier. The poor may be interested in making payments and remittances which is expected in developing countries. Credit provision is however what most banks consider core and financial regimes with interest rate ceilings have also supported this idea (Claessens, 2006). The traditional role of banks has to be challenged in the developing market to ensure inclusivity for all. Areas with poor security or low population density pose a problem to banks as this adds to the cost of doing business for banks.

Transactions by the poor may be small in size and this translates to the inability of each transaction to bear the high burden of variable or fixed cost (Helms, 2006). Weak systems i.e. legal and information infrastructure may affect the need for institutions to reach the unbanked (Claessens, 2006). These weak systems increase risk and cost of services thus making business propositions economically unrealistic. Market failures such as asymmetrical information, monopoly or oligopoly in the financial market and entry barriers to new competitors mean barriers for part of the population that will be excluded for reasons of price, risk and reduced supply (Claessens, 2006). Other supply side determinants include distance from branch, branch timings, language, staff attitude and tedious documentation and procedures. Overall, Supply side determinants have as a key effect, increased transactional costs.

Price and income are the predominant demand side economic barriers to access to financial services (Beck and De la Torre, 2006). The low (financial) literacy levels result in lower 
demand for services from formal providers (Honohan and King, 2009). Where there is less developed financial infrastructure, or just remote populations, then non-availability of formal financial services is expected (Beck, Demirguc-Kunt \& Martinea Peria, 2005). This is a particular concern in Africa as remote populations are expected in some countries.

Any challenges that hamper efforts towards financial inclusion at a national level are even more pronounced in rural areas (De Olloqui, Andrade \& Herrera, 2015). The sparse population density coupled by low income levels make a case for high operating costs which is then not attractive for mainstream financial services providers. This is further compounded by the population's low rate of property ownership which then translates to a lack of collateral should credit be sought. The users have limited financial capacities thus restricting demand, whereas the financial institutions provide services not quite suited to the needs of the population Villarreal, Stefanie, Jesus and Jesus (2017).

While measuring factors that influence financial inclusion indices, literature points to the relationship between rural population and financial inclusion (Sarma \& Pais, 2008; Yorulmaz, 2016). Findings by Yorulmaz (2016) indicate a negative relationship between rural population and financial inclusion. He concurs with the general observation that as one goes into rural parts of a country, financial inclusion levels overall decrease. There are fewer bank branches in rural areas and even these are spread far and thin. A bleak example is rural Madagascar where there exists one bank branch for 1.4 million people (CGAR, 2009).

Literature on financial inclusion identifies financial exclusion as a reflection of a broader problem of social exclusion. In nations characterized by high levels of industrialization and high levels of income, studies show that exclusion from the formal financial system occurs to people in the low-income groups, ethnic minorities and the elderly among others (Barr, 2004; Kempson \& Whyley, 1998; Connoly \& Hajaj, 2001). Countries that exhibit low levels of income inequality have high levels of financial inclusion (Buckland, Anderson, Burnham \& Jeffrey, 2005 and Kempson \& Whyley, 1998).

Kempson and Jones (2000) concluded that financial exclusion is majorly a function of having low income.Sinha and Subramanian (2007) then postulated that the leading cause of financial exclusion is a lack of steady income. The insignificant income gives them little incentive to open a savings account and as such, they are not eligible for a loan. The percentage of population living below the poverty line definitely influences the level of financial exclusion (Goyal, 2013). Mandira and Pais (2008) found out that income as measures by per capita GDP is an important factor in determining the level of financial inclusion in a country and that a household's economic status is positively correlated with degree of financial inclusion. This was in their cross country analysis of 49 countries using data for the year 2004.

It is less likely for the unemployed, those with irregular income and those with insecure employment to take part in the financial system. In the UK it was identified that payment of wages through automated cash transfer promoted financial inclusion (Goodwin Adelman \& Middleton, 2000). Financial exclusion is significantly propagated by payment of social security benefits and state pension in cash (Kempson \& Whyley, 1999).Argentina in 2001 made it mandatory for all firms to pay their employees' wages through a bank account. These accounts, referred to as wage accounts, attract no charges to the owner since May 2010. This development led to a significant increase in number of banked people in Argentina (Tuesta, et al., 2015). In 2008, Ireland through the Survey of Income and Living Conditions (SILC) established that $34 \%$ of households headed by an unemployed person did not have a bank current account. Further, $88 \%$ of unemployed Irish did not have any form of savings account (Russel, Maitre \& Donnelly, 2011). 
In less developed countries, the informal economy accounts for a significant share of the employed. Formal sector employment in the world implies participation in the formal financial system as wages and salaries are channeled through the formal banking system (ILO, 2001). The proportion of formal sector employment should be a good indicator of the degree of financial inclusion. Findings by Yorulmaz (2016) indicate that unemployment is negatively related with financial inclusion thus affirming that the unemployed and the irregularly employed will be less likely to be formally included. Bendig, Giesbert and Steiner (2009) found that literacy, ownership of assets and employment status enhanced adoption of financial services in Ghana.

The table below show the operationalisation of variables in the study.

Operationalisation of Variables

\begin{tabular}{|c|c|c|c|c|}
\hline Variable & Variable Type & Indicators & $\begin{array}{l}\text { Denoted } \\
\text { by }\end{array}$ & $\begin{array}{l}\text { Measurement } \\
\text { Type }\end{array}$ \\
\hline $\begin{array}{l}\text { Rural } \\
\text { Population }\end{array}$ & $\begin{array}{l}\text { Independent } \\
\text { Variable }\end{array}$ & $\begin{array}{l}\text { Rural population of a } \\
\text { country as a percentage of } \\
\text { total population }\end{array}$ & $R u P$ & Ratio \\
\hline Income & $\begin{array}{l}\text { Independent } \\
\text { Variable }\end{array}$ & $\begin{array}{l}\text { Growth in GDP per capita } \\
\text { (2010 USD) }\end{array}$ & $\operatorname{Inc}$ & Ratio \\
\hline $\begin{array}{l}\text { Unemployment } \\
\text { rate }\end{array}$ & $\begin{array}{l}\text { Independent } \\
\text { Variable }\end{array}$ & $\begin{array}{l}\text { Unemployed population as } \\
\text { a percentage of total } \\
\text { labour force }\end{array}$ & Une & Ratio \\
\hline Interest rate & $\begin{array}{l}\text { Independent } \\
\text { Variable }\end{array}$ & Real interest rate & Int & Ratio \\
\hline $\begin{array}{l}\text { Financial } \\
\text { Inclusion }\end{array}$ & $\begin{array}{l}\text { Dependent } \\
\text { Variable }\end{array}$ & $\begin{array}{l}\text { Domestic credit to private } \\
\text { sector by banks }(\% \text { of } \\
\text { GDP) }\end{array}$ & $Y$ & Ratio \\
\hline
\end{tabular}

\subsection{Research Methodology}

This study adopted a cross country panel design which aims to provide multiple observations across the population under examination. Panel data contains more degrees of freedom (Hsiao, 2007), has greater capacity to capture complexity of behaviour, and uncovers dynamic relationships - "Economic behaviour is inherently dynamic so that most econometrically interesting relationship are explicitly or implicitly dynamic"(Nerlove, 2002, p.5) and controls the impact of omitted variables.

The variables are expressed as follows:

$\mathrm{Y} \quad$ Domestic credit to private sector by banks (as a \% of GDP);RuP: Rural Population, Inc: GDP per capita, Une: Unemployment rate and Int: Real Interest rates.

The first model to be fitted was the Pooled Ordinary Least Squares which is the basic regression model as follows: 
$Y_{i, t}=\beta_{0}+\beta_{1} R u P_{1 i, t}+\beta_{2} I n c_{2 i, t}+\beta_{3} U_{n e_{3 i, t}}+\beta_{4} I n t_{4 i, t}+\varepsilon_{i, t}$

The Fixed Effects model was as follows:

$Y_{i, t}=\beta_{0}+\beta_{1} R u P_{1 i, t}+\beta_{2} I n c_{2 i, t}+\beta_{3} U_{n e} e_{3 i, t}+\beta_{4} \operatorname{Int}_{4 i, t}+\alpha_{i}+\varepsilon_{i, t}$

where $\alpha_{i}$ is the dummy accounting for any fixed effects

The Random Effects model was as follows:

$Y_{i, t}=\beta_{0}+\beta_{1} R u P_{1 i, t}+\beta_{2} \operatorname{Inc}_{2 i, t}+\beta_{3} U_{n e} e_{3 i, t}+\beta_{4} \operatorname{Int}_{4 i, t}+\lambda_{i}+\varepsilon_{i, t}$

where $\lambda_{i}$ is the dummy accounting for any random effects

\subsection{DATA ANALYSIS AND DISCUSSION OF FINDINGS}

\subsection{DATA ANALYSIS}

Before fitting any models, the author sought to explore the data in order to understand underlying structure and test any underlying assumptions in the data such as stationarity and correlation. The multicollinearity test is an evaluation of whether independent variables are linearly correlated. Correlation analysis provides a value that shows whether changes in the dependent variable are caused by changes in the independent variable. The correlation coefficient then measures the linear association between two variables (Crossman 2013).

Table 4.1 Correlation Matrix at $5 \%$ significance

\begin{tabular}{llllll}
\hline & $\mathbf{Y}$ & RuP & Inc & Une & Int \\
\hline $\mathbf{Y}$ & 1.0000 & & & & \\
RuP & -0.1978 & 1.0000 & & & \\
Inc & -0.2123 & -0.3925 & 1.0000 & & \\
Une & 0.7260 & -0.3497 & -0.0683 & 1.0000 & \\
Int & -0.0437 & -0.0194 & 0.1865 & -0.0426 & 1.0000 \\
\hline
\end{tabular}

None of the independent variables are highly correlated i.e. none of them have a correlation coefficient greater than 0.8 as is shown in the correlation matrix. Unemployment was the only independent variable that is positively correlated with the dependent variable. Rural population, income and interest rates all exhibited a negative correlation with financial inclusion. 
Table 4.2 Collinearity Diagnostics Table

\begin{tabular}{lllll}
\hline Variable & VIF & SQRT VIF & Tolerance & R-Squared \\
\hline Y & 2.24 & 1.50 & 0.4458 & 0.5542 \\
RuP & 1.43 & 1.19 & 0.7012 & 0.2988 \\
Inc & 1.37 & 1.17 & 0.7312 & 0.2688 \\
Une & 2.33 & 1.53 & 0.4284 & 0.5716 \\
Int & 1.04 & 1.02 & 0.9610 & 0.0390 \\
\hline Mean VI & 1.68 & & & \\
\hline
\end{tabular}

To further preclude multicollinearity, a collinearity test was undertaken. The VIF (Variance Inflation Factor) measures how much the variance of an estimated regression coefficient increases if independent variables are correlated. The collinearity test revealed that the mean VIF was 1.68 which is less than 5 and as such, there was no need to drop any variable.

\section{Test for Stationarity}

The study carried out a panel unit root test on all variables to preclude instance of spurious (non-sense) regression due to lack of stationarity. The Levin-Lin-Chu unit root test was adopted for this study. The Levin-Lin-Chu test was adopted as it does not allow for the possibility of the variable of a country to contain unit roots whereas for another country the same variable contains unit roots (Levin, Lin \& Chu,2002).

The problem in panels is that they are rarely independent of one another. For instance, affairs in Kenya affect what happens in Uganda and Tanzania. To further compound this, all these countries are members of the East African Community. This is referred to as cross-sectional interdependence, a phenomenon familiar in the social sciences since the1930s (Sarafidis \& Wansbeek, 2010). This is often ignored but could lead to issues in panel unit root testing. Demeaning the panels per time unit reduces these issues. All variables are stationary and can be used in a model without the need to use first differences. 


\section{Table 4.3 Stationarity Table using Levin-Lin-Chu unit-root test}

Ho: Panels contain unit roots

Ha: Panels are stationary

\begin{tabular}{lll}
\hline Variable & Test Statistic & p-value \\
\hline Y & -3.2147 & 0.0007 \\
RuP & -8.5169 & 0.0000 \\
Inc & -3.1856 & 0.0007 \\
Une & -2.2601 & 0.0119 \\
Int & -3.7434 & 0.0001 \\
\hline
\end{tabular}

\section{Diagnostic Tests}

Diagnostic tests were carried out to determine the best model to fit. As the study has panel data, the models available for use are either Pooled Ordinary Least Squares or Panel Data models which are Fixed Effect model or Random Effect model.

The table below shows results of the fitted models.

Table 4.5 Results of fitting the Fixed Effects, Random Effects and POLS models

\begin{tabular}{llll}
\hline $\begin{array}{l}\text { Independent } \\
\text { Variables }\end{array}$ & Fixed Effects & Random Effects & POLS \\
\hline Constant & $0.9218^{* * *}$ & 0.1270 & 0.1270 \\
& $(0.0000)$ & $(0.116)$ & $(0.120)$ \\
RuP & $-0.9412^{* * *}$ & -0.0189 & -0.0189 \\
& $(0.000)$ & $(0.839)$ & $(0.839)$ \\
Inc & 0.0896 & $-0.4429^{*}$ & $1.3866^{*}$ \\
& $(0.406)$ & $(0.040)$ & $(0.044)$ \\
Une & -1.3501 & $1.3867^{* * *}$ & $2.9586^{* * *}$ \\
& $(0.669)$ & $(0.000)$ & $(0.000)$ \\
Int & 0.0237 & 0.0176 & 0.0176 \\
& $(0.482)$ & $(0.806)$ & $(0.807)$ \\
\hline $\mathbf{R}^{2}$ & 0.9255 & & 0.5608
\end{tabular}



$\mathbf{P}$
$0.0000^{\star * *}$
0.0000
$1.75 \mathrm{e}-08^{\star * *}$
Sum squared resid $\quad 0.0315$
0.2973
S.D. dependent var $\quad 0.0709$
0.1120
S.E. of regression $\quad 0.0203$
0.0771

Where ${ }^{*},{ }^{* *}$ and ${ }^{* * *}$ represent $0.05,0.01$ and 0.001 levels of significance respectively

Table 4.6 Results of Diagnostic Tests

\begin{tabular}{|c|c|c|}
\hline Test description & Test Outcome & Conclusion \\
\hline $\begin{array}{l}\text { Hausman Test: examines } \\
\text { whether the 'random effects } \\
\text { estimate is insignificantly } \\
\text { different form the unbiased } \\
\text { fixed effect estimate' (Kennedy, } \\
2008 \text { p.286). It uses the } \\
\text { 'covariance of an efficient } \\
\text { estimator with its difference } \\
\text { from an inefficient estimator is }\end{array}$ & $\begin{array}{l}\text { Test statistic }- \text { chi }(4) \\
=1598292.55 \\
\text { Prob }>\text { chi } 2=0.0000\end{array}$ & $\begin{array}{l}\text { If the Prob>chi2 is less than } \\
0.05 \text {, the null hypothesis is } \\
\text { rejected and the conclusion } \\
\text { was that the difference in } \\
\text { coefficients was systematic. } \\
\text { The null hypothesis was } \\
\text { rejected. The study concluded } \\
\text { that the fixed effect model } \\
\text { was favoured. }\end{array}$ \\
\hline
\end{tabular}

For the poolability test, it is necessary to run country by country OLS regressions and also one pooled OLS regression for comparison. The null hypothesis is that all slopes of the independent variables are the same across countries.

The test is such that if the calculated $F$ value is greater than the $F$ test table value, the null hypothesis is rejected.

The null hypothesis was rejected. The model to be used was therefore selected as the fixed effects model.

The fixed effects model was fitted with dummy variables for the years to test whether fixed time effects needed to be accounted for in the final model. The test was carried out under the assumption that there were no time effects that would warrant the introduction of dummy 
variables for the years 2000-2016 (less one). There were no time related fixed effects. hence no need to fit dummy time variables.

Homoscedasticity is an assumption that states that for the fitted model, the probability distribution is the same for all observations. Should the disturbance terms not have the same variance, this is referred to as heteroscedasticity (Garson, 2012). In order to detect any heteroscedasticity, the Modified Wald test for group wise heteroscedasticity (Greene, 2000) in fixed regression model was used. The model had a heteroscedasticity problem. This was corrected by applying robust standard errors when fitting the model (Stock \& Watson, 2008). The final model was reported with these errors instead.

\subsection{Model Fitting}

The results of fitting the model with robust standard errors to control for heteroscedasticity are as shown below.

\section{Table 4.7: Final model results}

Fixed-effects, using 85 observations

Included 5 cross-sectional units

Time-series length $=17$

Dependent variable: $Y$

Robust (HAC) standard errors

\begin{tabular}{lllll}
\hline & Coefficient & Std. Error & t-ratio & p-value \\
\hline Constant & $0.9220^{* * *}$ & 0.0918 & 10.04 & 0.001 \\
RuP & $-0.9412^{* *}$ & 0.1358 & -6.93 & 0.002 \\
Inc & $0.0896^{*}$ & 0.0262 & 3.42 & 0.027 \\
Une & -0.1350 & 0.4747 & -0.28 & 0.790 \\
Int & 0.0237 & 0.0369 & 0.64 & 0.556 \\
\hline $\begin{array}{l}\text { Mean dependent var } 0.160241 \\
\text { Sum squared resid } 0.031464\end{array}$ & S.D. dependent var 0.070924 \\
rho & 0.692040 & S.E. of regression & 0.020347 \\
\end{tabular}

Joint test on named regressors -

Test statistic: $F(4,4)=94380.5$

with $p$-value $=P(F(4,4)>94380.5)=0.0000$ 


\subsection{Discussion of Findings}

Rural population has a negative and significant relationship on financial inclusion. This negative relationship implies that financial inclusion levels decrease as one approaches the rural regions in a country, in this case by $94.12 \%$ per every unit increment in rural population. The findings on rural population are consistent with findings by Yorulmaz (2016) and Kempson and Whyley (2001) who found rural population size of a country to have a negative relationship with financial inclusion.

Income is a significant variable at $95 \%$.The income variable has an expected sign with a significant relationship with financial inclusion. As income grows, whose proxy is growth in GDP per capita, it is expected that financial inclusion shall increase. For this study, a unit increase in growth rate of GDP per capita led to an increase of $8.96 \%$ in financial inclusion. This is consistent with findings by Sarma and Pais (2008), Yorulmaz (2016) and Weill and Zins (2016). These past studies showed a positive relationship between income and financial inclusion.

Unemployment rate had an expected negative sign, indicating that as national levels of unemployment rise, financial inclusion levels reduce. The variable is however insignificant in explaining the levels of financial inclusion. These findings are consistent with findings by Sarma and Pais (2008) and Yorulmaz (2016) who found unemployment negatively but statistically significant in relation to financial inclusion.

Interest rates had a positive but insignificant relationship with financial inclusion. These findings are partially consistent with Sarma and Pais (2008) and Olaniyi and Babatunde (2016) who found a positive relationship between interest rates and financial inclusion.

Following the analysis, the model fitted based on significant variables was as follows:

$Y=0.9220-0.9412 R u P+0.0896 \operatorname{Inc}$

\subsection{Summary and Recommendations}

\subsection{Summary}

A number of logical conclusions were drawn from this study. Rural population and income are the two significant determinants of financial inclusion in East Africa. Consistent with the results, it is expected that with an increase in the rural population of a country, there is bound to be a decrease in financial inclusion levels of a country. Countries with increased GDP per capita will have more inclusive financial systems thus have higher levels of financial inclusion. This is consistent with findings by earlier researchers.

In East Africa however, unemployment rates and interest rates are not significant determinants of financial inclusion. Unemployment rates are negatively related to financial inclusion and an increase in unemployment rates in East African countries will lead to a reduction in financial inclusion levels. It is agreed that this would be an expected outcome for this variable. The study also concludes that interest rates though insignificant have a positive influence on financial inclusion.

\subsection{Recommendations}

The findings of this study are important to policy makers, banking sector specialists and advisors to banks. Rural population as a determinant of financial inclusion points to the need 
for expansion of financial services to the rural areas or urbanising more parts of a country through provision of infrastructure. Financial literacy in the rural areas can help in the campaign for financial inclusion. Based on the demographics of the rural population as well, the financial literacy campaigns can also be more targeted e.g. on women, specific religious communities or even a specific age group. Further, alternative approaches to availing banking infrastructure can be considered, such as agency banking. The population living in the rural areas also suffer from financial handicaps especially considering the seasonality of their income and any migration that is brought about by job seeking. To temper this, banking products need to be tailored to address the varying needs of the rural population.

The study sought to establish the determinants of financial inclusion in East Africa. Future research should consider using a more robust measure of financial inclusion that captures the different aspects of financial inclusion. The current study only adopted usage dimension of financial inclusion and ignored dimensions such as accessibility/ penetration of services, availability of services and quality of products. It would be advisable to also consider other variables that are considered determinants of Financial Inclusion such as gender and religion.

\section{References}

Allen, F., Demirguc-Kunt, A., Klapper, L., Martinez, P. \& Maria, S. (2016). The foundations of financial inclusion: understanding ownership and use of formal accounts (English). Policy Research Working Paper No. WPS 6290. Washington, DC: World Bank Group. https://doi.org/10.1016/j.ji. 2015.12.003

Allen, F., Elena, C., Cull, R., Qian, J.Q.J., Senbet, L \& Valenzuela, Patricio. (2014). The African financial development and financial inclusion gaps. Journal of African Economies, 23. 614-642. 10.1093/jae/eju015.

Alpana, V. (2007). Promoting financial inclusion: an analysis of the role of banks. Indian Journal of Social Development, 7(1), 107-26.

Attanasio, O., Augsburg, B., Ralph de Haas, Emla Fitzsimons, \& Heike Harmgart, (2011). Group lending or individual lending? Evidence from a randomised field experiment in Mongolia. Working Paper No. W11/20. London: Institute for Fiscal Studies. https://doi.org/10.2139/ssrn.1974414

Bagehot, W. (1873). Lombard Street: A description of the money market. Scribner, Armstrong

Barr, M. (2004). Banking the poor, Yale Journal on Regulation 21, 122-239.

Bauchet, J., Cristobal M., Starita,L., Thomas, J. \& Anna Yalouris. (2011). Latest findings from randomized evaluations of microfinance. Forum 2. Washington, D.C.: CGAP, Financial Access Initiative, Innovations for Poverty Action, and Abdul Latif Jameel Poverty Action Lab. https://doi.org/10.1596/26892

Beck T. and Brown M. (2011). Which households use banks? Evidence from the transition economies. European Central Bank, Conference on Household Finance and Consumption, Working Paper series No 1295.

Beck, T., Demirgüç-Kunt, A., \& Levine, R. (2006). Bank concentration competition, and crises: First results. Journal of Banking \& Finance, 30(5), 1581-1603. https://doi.org/10.1016/j.jbankfin.2005.05.010 
Beck T., Demirguc-Kunt, A. \& Martinez Peria, M. (2005). Reaching out: Access to and use of banking services across countries. Policy Research Working Paper; No. 3754. World Bank, Washington, DC. https://doi.org/10.1596/1813-9450-3754

Beck, T., and De la Torre, A. (2006). The basic analytics of access to financial services (Vol. 4026). World Bank-free PDF. https://doi.org/10.1596/1813-9450-4026

Bendig, M., Giesbert, L. and Steiner, S. (2009). Savings, credit and insurance: Household demand for formal financial services in rural Ghana. Working Paper No.94, German Institute of Global and Area Studies.

Benston G.W. \&Smith, C.W. (1976). A transaction cost approach to the theory of financial intermediation. The Journal of Finance, Vol. XXXI (1), pp. 215-231. https://doi.org/10.2307/2326596

Boichev, G.,Buckland, J.,Geddie, H., Guenther, B.\& Mutch, M. (2005). There are no banks here: Financial and insurance exclusion services in Winnipeg's north end. Winnipeg Inter-City Research Alliance (WIRA), Canada.

Brigit Helms (2006). Access for All: Building inclusive financial systems. World Bank. https://doi.org/10.1596/978-0-8213-6360-7

Buckland, T. S., Anderson, D. R., Burnham, K. P. \& Jeffrey, L. (2005). Distance sampling. 10.1002/0470011815.b2a16019.

Chow, G. (1960), Tests of equality between sets of coefficients in two linear regressions. Econometrica, 28, 531-534. https://doi.org/10.2307/1910133

Claessens, S. (2006). Access to financial services: A review of the issues and public policy objectives. The World Bank Research Observer, 21(2). https://doi.org/10.1093/wbro/lkl004

Cnaan, R. A.,Handy, F. \& Moodithaya, M. S. (2012). Financial inclusion: Lessons from rural South India. Journal of Social Policy, 41(1): 183-205. https://doi.org/10.1017/S0047279411000377

Connolly, C. \& Hajaj, K. (2001), Financial Services and Social Exclusion. Financial Services Consumer Policy Centre, University of New South Wales.

Crossman, A. (2013). Convergence theory. About.com sociology. Retrieved December 04, 2013, from http://sociology.about.com/od/C_Index/g/Convergence-Theory.htm

Cuijpers, R. (2009). GDP and happiness: Gross national happiness, the new GDP? Erasmus School of Economics Department of Applied Economics.

Cull, R., Demirgüç-Kunt, A., Morduch, J. (2009). Microfinance meets the market. Journal of Economic Perspectives 23: 167-192. https://doi.org/10.1257/jep.23.1.167

Demirguc-Kunt, A., and Klapper, L. (2013). Measuring financial inclusion: The global findex database. Brookings Papers on Economic Activity. https://doi.org/10.1596/1813-9450-6025

De Olloqui, F., Andrade, G. \& Herrera D. (2015). "Inclusión fnanciera en América Latina y el Caribe: coyuntura actual y desafíos para los próximos años", IDB Discussion Paper, No. 385, Washington, D.C., Inter-American Development Bank (IDB). https://doi.org/10.18235/0000030

Diamond D. (1984). Financial intermediation and delegated monitoring. Review of Economic Studies 51:. 393-414. https://doi.org/10.2307/2297430

Fama E.F. (1980). Fama banking in the theory of finance. Journal of Monetary Economics, 6 (1): 3957. https://doi.org/10.1016/0304-3932(80)90017-3 
Fuller, D. \& Mellor, M. (2008). Banking for the poor: Addressing the needs of financially excluded communities in Newcastle upon Tyne. Urban Studies, 45(7): 1505-24. https://doi.org/10.1177/0042098008090686

Garson G. D. (2012). Hierarchical linear modelling: Guide and applications. Thousand Oaks, CA: Sage Publications, Inc.

Goodwin, D., Adelman, L., \& Middleton, S. (2000).Debt, money management and access to financial services: Evidence from the 1999 PSE survey of Britain. Working Paper No. 8. Bristol: Centre for Research in Social Policy, University of Bristol.

Greene, W. (2000). Econometric analysis. Prentice-Hall, New York.

Gurley, J.G. \& Shaw, E.S. (1960). Money in a theory of finance. The Brookings Institution, Washington, D.C.

Guttentag, J. M. \&Lindsay, R. (1968). The uniqueness of commercial banks. Journal of Political Economy (71): 991-1014. https://doi.org/10.1086/259464

Hall, S. G. and Urga, G. (2000). New developments in the analysis of panel data sets, in The Current State of Business Disciplines, Vol. 2, Chapter 28 (Ed). Spellbound Publications PVT Ltd., Rohtak (Business Economics): 537-64.

Honohan, P. \& King, M. (2009). Cause and effect of financial access: Cross country evidence from the finscope surveys. Prepared for the World Bank Conference, "Measurement, Promotion, and Impact of Access to Financial Services". Washington DC, March 12-13, 2009

Hsiao, C. (2007). Panel data analysis - advantages and challenges. TEST 16: 1 - 22. https://doi.org/10.1007/s11749-007-0046-x

ILO (2002).Women and men in the informal economy: A statistical picture. International Labour Office, Geneva.

Johnston, D. \& Morduch, J. (2008). The unbanked: evidence from Indonesia. World Bank Economic Review 22(3): 517-537. https://doi.org/10.1093/wber//hn016

Karlan, D. \& Morduch, J. (2009). Access to Finance, Handbook of Development Economics, Volume 5. https://doi.org/10.1016/B978-0-444-52944-2.00009-4

Karlan, Dean \& Jonathan Zinman. (2010). Expanding credit access: Using randomized supply decisions to estimate the impacts. Review of Financial Studies, 23: 433-64. https://doi.org/10.1093/rfs/hhp092

Kempson, E. \& Whyley, C. (1998). Access to Current Accounts, British Bankers' Association, London.

Kempson, E. \& Jones, T. (2000). Banking without branches: A study of how people conduct their banking business without a local branch. British Bankers' Association, London.

Kempson, E. \& Whyley, C. (1999). Kept out or opted out? Understanding and combating financial exclusion. Policy Press, Bristol.

Kennedy, Peter. 2008. A Guide to Econometrics, 6th ed. Malden. Blackwell Publishing, MA.

Kuri, P. D. \& Laha, A. (2011). Determinants of financial inclusion: A study of some selected districts of West Bengal, India.

Levin, A., C.-F. Lin, and C.-S. J. Chu. (2002).Unit root tests in panel data: Asymptotic and finite-sample properties. Journal of Econometrics 108: 1-24. https://doi.org/10.1016/S0304-4076(01)00098-7 
Leyshon A. (2009) 'Financial exclusion'. In R. Kitchin \& N. Thrift (Eds) International Encyclopedia of Human Geography. Oxford: Elsevier, Volume 4, pp. 153-8. https://doi.org/10.1016/B978008044910-4.00160-7

Losch, B., Freguin-Gresh, S. \& White, E.T. (2012). Structural transformation and rural change revisited: Challenges for late developing countries in a globalizing world. Africa Development Forum; Washington, DC: World Bank. (c) World Bank. https://openknowledge.worldbank.org/handle/10986/12481 License: CC $\quad$ BY 3.0 IGO. https://doi.org/10.1596/978-0-8213-9512-7

Luebker, M. (2008). Employment, unemployment and informality in Zimbabwe: Concepts and data for coherent policy-making. Issues Paper no. 32.

Marwa, N. \& Zhanje, S. (2015). A review of finance-growth nexus theories: How does development finance fit in? https://doi.org/10.1515/sbe-2015-0007

Naceur, M. S. B., Barajas, M. A., \& Massara, M. A. (2015). Can Islamic banking increase financial inclusion? (International Monetary Fund, No. 15-31. https://doi.org/10.5089/9781498370813.001

National Financial Inclusion Coordination Structures: Country Examples. Retrieved 2017-10-18 from http://pubdocs.worldbank.org.

Nerlove, M. (2002). Essays in panel data econometrics, NEWBOOKS Services.

Olaniyi, E. \& Babatunde, A. (2016). Determinants of financial inclusion in Africa: A dynamic panel data approach. University of Mauritius Research Journal, 22.

Oyelami, L.O., Saibu, O. M. and Adekunle, B. S. (2017). Determinants of financial inclusion in SubSahara African countries.

Russell, H., Maître, B., \& Donnelly, N. (2011). Financial exclusion and over-indebtedness in Irish households. Department of Community, Equality \& Gaeltacht Affairs and Economic and Social Research Institute.

Sarafidis, Vasilis and Wansbeek, Tom (2010). Cross-sectional dependence in panel data analysis. Unpublished working paper, MPRA Paper No. 20815.

Sarma, M.and Pais, J. (2008). Financial inclusion and development: A cross country analysis.

Sarma, M. (2008). Index of financial inclusion. ICRIER Working Paper, August 2008.

Schumpeter, J. (1982). The theory of economic development. Transaction Publishers, New Jersey.

Scott, David (2003). Wall Street words: An A to Z guide to investment terms for today's investor. Houghton Mifflin Company, Boston.

Stock, James H. and Watson, Mark W. (2008). Heteroskedasticity-robust standard errors for fixed effect panel data regression. Econometrica 76(1). https://doi.org/10.1111/j.0012-9682.2008.00821.x

Sullivan, A. \& Sheffrin, M. S. (2005). Economics: Principles in action.: Pearson Prentice Hall.

Tuesta, D., Sorensen, G., Haring, A. \& Camara, N. (2015). Financial inclusion and its determinants: the case of Argentina.

Villarreal, F. G., Stefanie,G., Jesús, L. \&Jesús, S. (2017). Financial inclusion of small scale rural producers: trends and challenges. 
Were, M., Nzomoi, J. \& Rutto, N. (2012). Assessing the Impact of Private Sector Credit on Economic Performance: Evidence from Sectoral Panel Data for Kenya. International Journal of Economics and Finance, 4( 3). https://doi.org/10.5539/ijef.v4n3p182

Yorulmaz, R. (2016). Construction of a financial inclusion index for the member and candidate countries of the European Union.

Zins, A., Weill, L. (2016). The determinants of financial inclusion in Africa. Review of Development Finance 6(2016): 46-57. https://doi.org/10.1016/j.rdf.2016.05.001 